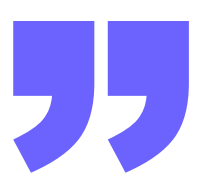

\title{
CODE SWITCHING FOUND IN CINTA LAURA'S VIDEO ON HER INSTAGRAM TV
}

\author{
Ni Made Dwi Yanti Wiraputri ${ }^{1}$, I Komang Sulatra ${ }^{2}$, I GB Wahyu \\ Nugraha Putra ${ }^{3}$ \\ English Study Program Faculty of Foreign Languages, Mahasaraswati \\ Denpasar University, Indonesia ${ }^{123}$ \\ tiwiyantii@gmail.com ${ }^{1}$, soelatra01@yahoo.com², \\ wahyunugraha1980@yahoo.com ${ }^{3}$
}

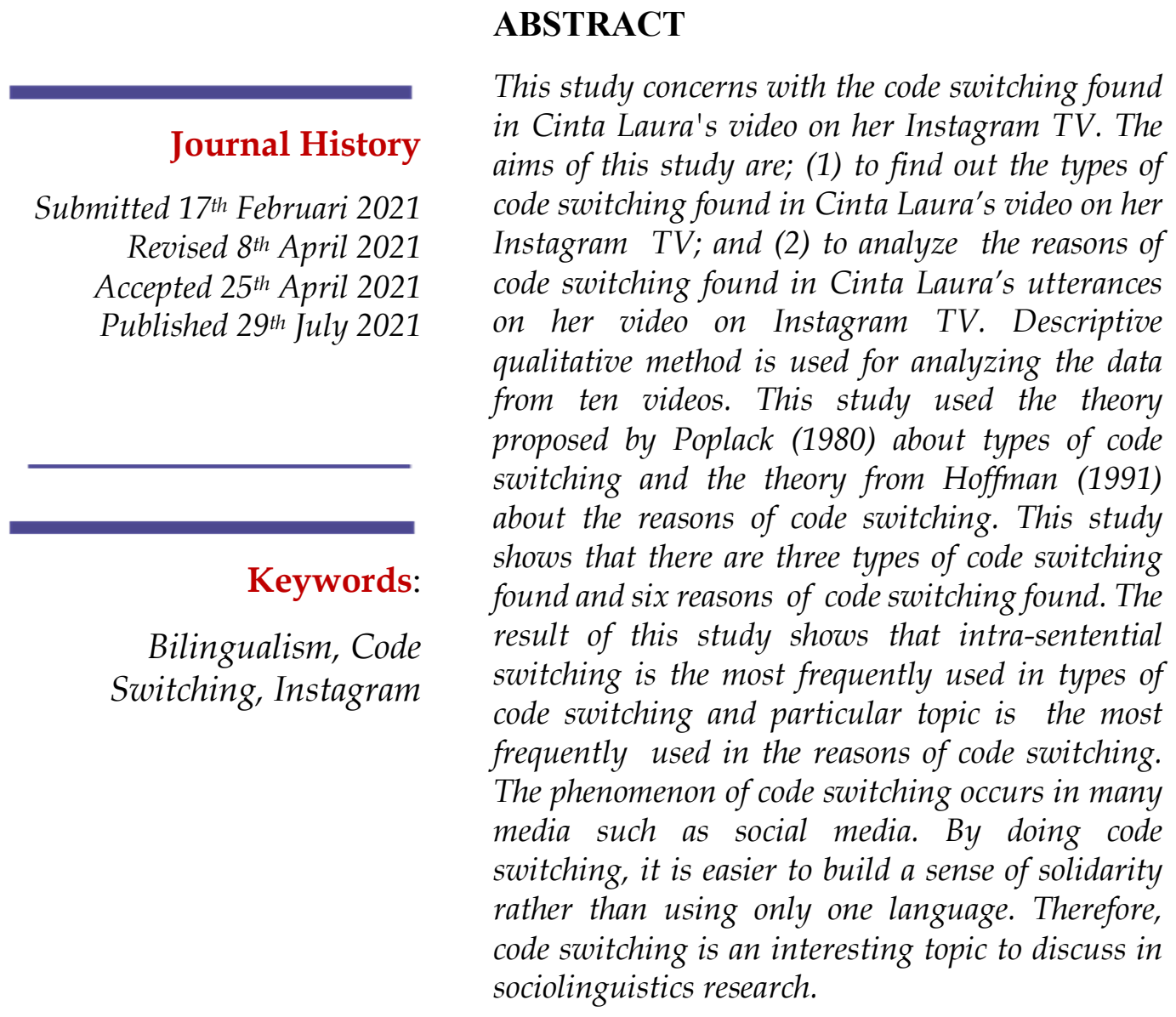

\section{INTRODUCTION}

Language as a communication tools or interaction tools that only possessed by humans. Language is communication tools that is the best, the most perfect, rather than other communication tools. According to Keraf (2005), "Language as communication tools between communities in the form of sound symbols to convey messages, thoughts, and feelings that 
produced by human speech." The character of human that always wants to interact, not only by using one language but with various languages in their lives to establish a good relationship or a bond, with the people form own countries as well as foreign countries. Therefore, intelligence and finesse to master the various languages is obtained from learning, therefore a person can speak a language other than his/her mother tongue. This ability of using two or more languages is called bilingualism. The ability of using two languages in any situation and anywhere make a person switch one language to other language in his/her utterances, so this phenomenon is called code switching.

Code switching has become a common term for the alternate use of two or more languages, varieties of language, or even speech styles (Hymes 1875: 103). Code switching can be found on TV programs, songs, novels, and social media. Nowadays, social media is the famous place where we could find code switching because many people used social media to expressed their own thoughts and feelings through language used. The most active social media used by the people is instagram. Instagram is a unique application where the people can upload photos or videos at will, even there is a new feature on instagram right now is Instagram TV or better known as IGTV, where the people can upload videos with a longer duration and this is also can referred as to create their own TV broadcast. All of the people can use the instagram application, including an actress, one of example is Cinta Laura. Cinta Laura has the real name Cinta Laura Keihl who is an Indonesian actress, singer, and model. The phenomenon of code switching in Cinta Laura's videos can be found easily because she is an Indonesian who can speak English fluently and always mixing and changing the language in a conversation.

There are many researches about code switching analysis that have been conducted by researchers. They tend to analyze the types and factors in the twitter and TV program. As it is done by Yunandra (2016), she analyzed Indonesian Artists' Twitter Tweets. She found tweets which showed the combination of the code switching types. She also found that some tweets were not only influenced by one factor, but could be influenced by more than one factor. Another research by Dianti (2018) which analyzed Code Switching and The Construction of Young Professional Identity in NET TV's Breakout. She found that the data mostly use the type of metaphorical code switching and situational code switching. She also found that the most factor that motivate the hosts when switch the language was the topic, participant, and setting.

Meanwhile, for this research could be compared with those two previous researchers has the similarity and differences. The similarity is the topic that analyzed same about the types of code switching. For the difference is the data sources that analyzed are different. This research 
analyzed the data from Instagram TV while those previous research analyzed from twitter and TV program. The difference also found in the topic that analyzed, this research analyzed the reason of using code switching, while those two previous research analyzed the factor of using code switching.

The researcher is interested in choosing Instagram TV because Instagram TV is the new findings to research because no one used Instagram TV as a data source yet. The objectives of this research are; (1) to find out the types of code switching found in Cinta Laura's video on her instagram TV, (2) to analyze the reasons of code switching found in Cinta Laura's utterances on her video of instagram TV. The researcher choosing Cinta Laura's video on Instagram TV because Cinta Laura always post the content about positive things and inspire many people. By analyzing the videos, the researchers expect to give a better understanding about the phenomenon of code switching.

\section{METHODS}

The data source of this research was taken from Cinta Laura's utterances on her Instagram TV. The data source was found in Cinta Laura's instagram account @ cintalaurakiehl. There were ten videos taken from Instagram TV, those are; (1) Pangerasan Education Center: School Visit with duration 4:11, (2) Apa Isi Tasku? with duration 16:40, (3) What YOU made me do in Korea! with duration 4:32, (4) The Real Story Behind Cinta Laura Kiehl with duration 3:45, (5) Hari Kartini 2020 with duration 8:37, (6) Selamat Hari Lahir Pancasila with duration 6:01, (7) Ayo Dukung Program Pundi Perempuan with duration 1:38, (8) Woman In Progress Di Mataku with duration 6:06, (9) PFpreneur Women In Business with duration 1:40, (10) Apakah perempuan mempunyai keterbatasan? with duration 1:20.

A library research was conducted in this study. This research applied observation method in collecting the data. There were several techniques were done in collecting data, those are; (1) Searching Cinta Laura's instagram account and select various videos that related to code switching, (2) Watching and listening repeatedly the video that has been selected, (3) Note taking the data that related to code switching, (4) Determining the data based on the types and the reasons of code switching. In this research, descriptive qualitative method was used in analyzing the data. The data was described systematically in accordance with code switching theory proposed by Poplack (1980) and Hoffman (1991). The result of data was presented in formal and informal way. In formal method, the data were shown in table to show the occurrence and percentage for types and the reasons of code switching. In informal method, the data were presented in the form of description through using word, sentences and paragraph. 


\section{RESULTS AND DISCUSSION}

\section{RESULTS}

The result is divided into two parts, there are types of code switching proposed theory by Poplack (1980) and the reasons of code switching proposed theory by Hoffman (1991).

\section{Types of Code Switching}

Poplack (1980) divides the types of code switching into three types, those are tag switching, inter-sentential switching, and intra-sentential switching. Each type were counted into percentage based on formula below:

Formula:

$$
\begin{aligned}
& F=\frac{n}{\sum \mathrm{N}} \times 100 \\
& F \quad=\text { Percentage of each types of code switching } \\
& n \quad=\text { Occurrence of each types of code switching } \\
& \sum \mathrm{N} \quad=\text { Total occurrence of types of code switching }
\end{aligned}
$$

\section{Tabulation of Types of Code Switching found in 10 videos on Cinta Laura's Instagram TV}

\begin{tabular}{l|lll}
$\mathbf{n}$ no & Types of Code Switching & Occurrence & Percentage (\%) \\
\hline $\mathbf{1}$ & Tag Switching & 8 & $8,70 \%$ \\
\hline $\mathbf{2}$ & Inter-sentential Switching & 34 & $36,95 \%$ \\
\hline & Intra-sentential Switching & 50 & $54,35 \%$ \\
\hline & TOTAL & $\mathbf{9 2}$ & $\mathbf{1 0 0} \%$
\end{tabular}

The table above shows the total data of code switching found which are 92 code switching. As the result, intra-sentential switching become the most frequently used in the video of Cinta Laura's Instagram TV (IGTV) with $54,35 \%$ of the percentage because Cinta Laura oftentimes switches one language to the other language in her utterance. Cinta Laura said many English words or sentences that put within sentence or clause without comma. Tag switching are less used in her utterances with $8,70 \%$ of the percentage because Cinta Laura rarely put a tag phrase in her utterances.

\section{The Reasons of Code Switching}

Hoffman (1991) proposed the reasons of code switching into six reasons, those are particular topic, quoting someone's word, being emphatic about something, interjection, repetition used for clarification, 
and expressing group identity. Each the reasons were counted into percentage based on formula below:

Formula:

$F=\frac{n}{\sum \mathrm{N}} \times 100$

$F \quad=$ Percentage of each the reason of code switching

$n \quad=$ Occurrence of each the reason of code switching

$\sum \mathrm{N}=$ Total occurrence of the reason of code switching

\section{Tabulation of The Reasons of Code Switching found in 10 videos on} Cinta Laura's Instagram TV

\begin{tabular}{l|l|l|l} 
N & The Reasons of Code Switching & Occurrence & Percentage (\%) \\
\hline $\mathbf{1}$ & Particular topic & 42 & $\mathbf{4 5 , 6 5 \%}$ \\
\hline $\mathbf{2}$ & Quoting someone's word & 1 & $\mathbf{1 , 0 8 \%}$ \\
\hline $\mathbf{3}$ & Being emphatic about something & 36 & $39,13 \%$ \\
\hline $\mathbf{4}$ & $\begin{array}{l}\text { Interjection (inserting sentence fillers } \\
\text { or sentence connectors) }\end{array}$ & 2 & $\mathbf{2 , 1 8 \%}$ \\
\hline \multirow{2}{*}{$\mathbf{5}$} & Repetition used for clarification & 4 & \\
\hline $\mathbf{6}$ & Expressing group identity & 7 & $\mathbf{4 , 3 5 \%}$ \\
\cline { 2 - 4 } & TOTAL & 92 & $\mathbf{7 , 6 1 \%}$ \\
\end{tabular}

The table above shows the total data of code switching found which are 92 code switching. As the result, particular topic become the most frequently used in the video of Cinta Laura's Instagram TV (IGTV) with $45,65 \%$ of the percentage because Cinta Laura oftentimes used English words if she cannot find an appropriate word or any expression in Indonesian language. Quoting someone's word is less used in her utterances with $1,08 \%$ of the percentage because Cinta Laura rarely put a someone's quote in her utterances.

\section{DISCUSSION}

The discussion is divided into two parts. The first is types of code switching by using theory from Poplack (1980), second is the reasons of code switching by using from Hoffman (1991). The data are analyzing by sentences based on the theory. The explanation is below: 


\section{Tag Switching and The Reasons}

\section{Data 1}

"Alright, sebelum 5 menit polingnya lebih banyak yang real apple store daripada yang apple $k w^{\prime \prime}$

(Alright, before 5 minutes the polling of the real apple store is more than apple kw) Source: What you made me do in Korea! - (2:55 - 3:05)

The data above shows that the first utterance is "Alright" by using English language. The word "Alright" is the shorter way to speak which no need many statement because the word "Alright" can stay alone without many words or sentences. The word "Alright" in indonesian is "Baiklah", is used in expressing for assent, agreement or acceptance. The insertion of this word does not violate the grammar as the characteristic of tag switching. Based on the analysis, the data above is categorized as tag switching. The reason of uttering "Alright" as the case of tag switching is because particular topic. Cinta Laura is having lack of ability in Indonesian then she chose the tag "Alright", she felt more comfortable and more familiar with that word.

\section{Data 2}

"Wow! Ini momen yang sangat spesial di hidup aku karena di saat itu aku bisa lulus dari salah satu universitas dalam 3 tahun di umur masih muda."

(Wow! This is a very special moment in my life because at that time I was able to graduate from a university in 3 years at a young age)

\section{Source: Woman in Progress Di Mataku - (1:03 - 1:27)}

In the sentences above, the insertion of the word "Wow!" with exclamation in the first utterance by English language and then switched into Indonesian language "Ini momen yang sangat spesial di hidup aku karena di saat itu aku bisa lulus dari salah satu universitas dalam 3 tahun di umur masih muda." This word does not break and violate the grammar as the characteristic of tag switching. Based on the analysis, the data is categorized as tag switching. The data above can be classified into the reason of code switching that is interjection because Cinta Laura said a short exclamation "Wow!" to express her feeling, it happens unintentionally or intentionally. The word "Wow!" has no grammatical value as the characteristic of interjection.

"Aku juga bukan anak kecil yang dipaksa untuk ngelakuin sesuatu yang aku gak mau. I'm adult now and I really wanna take the lead." 
(I also not a child who is forced for to do something that I do not want to do. I'm adult now and I really wanna take the lead)

Source: The Real Story Behind Cinta Laura Kiehl - (2:33 - 2:40)

The sentence above involved a switch between a sentence in one language to the other language as the characteristic of inter-sentential switching. Based on the theory from Poplack (1980), inter-sentential switching involves a switch after sentence boundary. Indonesian language in the first utterance "Aku juga bukan anak kecil yang dipaksa untuk ngelakuin sesuatu yang aku gak mau.", then switched into English language "I'm adult now and I really wanna take the lead." The reason of uttering "I'm adult now and I really wanna take the lead" in English as the case of inter-sentential switching is because being emphatic about something. Cinta Laura wanted to being emphatic something by emphasize her utterance in English so make the audience understand what she felt. In Indonesian is "Saya sudah dewasa sekarang dan saya benar-benar ingin memimpin." Her utterance is about she does not want to restrained in her life or career.

\section{Data 4}

"We can continue to remind the Indonesian women that they have choice in live. Apapun itu mau itu untuk buat keluarga atau menjadi CEO, dokter, apapun bidangnya."

(We can continue to remind the Indonesian women that they have choice in live. Anything for the family or become a CEO, a doctor, anything the field is)

Source: Apakah perempuan mempunyai keterbatasan? - (0:42 - 0:50)

In the sentence above, in the beginning of the utterance "We can continue to remind the Indonesian women that they have choice in live" by English language, then switched into Indonesian "Apapun itu mau itu untuk buat keluarga atau menjadi CEO, dokter, apapun bidangnya". It can be seen that her utterance from English language to Indonesian language after sentence boundary, as the characteristic of inter-sentential switching. The reason of uttering "We can continue to remind the Indonesian women that they have choice in live" in English as the case of inter-sentential switching is because being emphatic about something. Cinta Laura wanted to being emphatic something by emphasize her utterance in English to make the audience easily understand what she said about we as women can continue to remind each other that they have choice in live, we can do anything and there are not limit.

"United nations women mencatat bahwa permintaan rumah aman bagi korban- korban kekerasan semakin meningkat tajam." 
(United nations women noted that the demand for safe houses for victims of violence has increased sharply)

Source: Ayo Dukung Program Pundi Perempuan - (0:10 - 0:18)

The sentence above was uttered by using two languages. The first started with English language "United Nations Women", then connected to Indonesian language "mencatat bahwa permintaan rumah aman bagi korban-korban kekerasan semakin meningkat tajam". The switch of language occurred within a sentence, it can be categorized as intrasentential switching. The reason of uttering "United Nations Women" as the case of intra-sentential switching is because express group identity. Cinta Laura mentions the group of United Nations Women in her utterance about the victims of violence that increased sharply. The word "United Nations Women" means International organization that was formed as a dedicated to gender equality and the empowerment of women. Cinta Laura used English language because the name of United Nations Women has been known in the world so that the people can easily understand.

Data 6

“Untuk sementara aku percaya bahwa kita semua punya suara, gak harus jadi celebrity atau influencer untuk menjadi role model yang baik buat orang-orang disekitar kita."

(For a while I believe that we're all have a ballot, don't have to be a celebrity or influencer for become a good role model for the people around us)

Source: Selamat Hari Lahir Pancasila - (3:57 - 4:07)

Intra-sentential switching appears in several places in sentence above. The inserted of the English word "celebrity", "influencer", and "role model" in the middle of Indonesian language. The word "celebrity" and "influencer" as a noun phrase, and "role model" as a phrase. Based on the analysis, the data above can be categorized as intra-sentential switching because the switching occurs in the form of noun phrase and phrase. Based on the theory from Poplack (1980), intra- sentential switching occurs in the form of sentence, word, phrase or clause. The inserted of the English word in Indonesian utterance also have the reasons. The reason of uttering "celebrity", "influencer", and "role model" as the case of intra- sentential switching is because particular topic. First, the word "celebrity" because she felt easier to uttered in English accent. Second, the word "influencer" because she cannot find an appropriate word to translations for the vocabulary needed in Indonesian language. Third, the word "role model" because she felt more comfortable and more familiar with that word in English. 


\section{CONCLUSION}

The conclusion in this research are divided into two main points. The first conclusion deals with types of code switching found in Cinta Laura's video on Instagram TV (IGTV). The second conclusion deals with the reasons of code switching found in Cinta Laura's video on Instagram TV (IGTV).

From the analysis, it can be concluded that the types of code switching occurred in Cinta Laura's instagram TV are intra-sentential switching which become the most frequently used in the utterance of Cinta Laura's video with $54,35 \%$ of the percentage because Cinta Laura oftentimes switches one language to the other language in her utterance. Cinta Laura said many English words or sentences that put within sentence or clause without comma. The second position that frequently used is inter-sentential switching with $36,95 \%$ of the percentage. Meanwhile the last position is tag switching with $8,70 \%$ of the percentage because Cinta Laura rarely put a tag phrase in her utterances.

For the reason of code switching, it can be concluded that six reasons were found. The reason of code switching occurred in Cinta Laura's instagram TV are particular topic which become the most frequently used in the utterance of Cinta Laura's video with $45,65 \%$ of the percentage because Cinta Laura oftentimes used English words if she cannot find an appropriate word or any expression in Indonesian language. The second position that frequently used is being emphatic about something with $39,13 \%$ of the percentage. Then, expressing group identity with $7,61 \%$ of thepercentage, repetition used for clarification with $4,35 \%$ of the percentage, interjection with $2,18 \%$ of the percentage. Meanwhile, quoting someone's word is less used in her utterances with 1,08\% of the percentage because Cinta Laura rarely put a someone's quote in her utterances.

\section{ACKNOWLEDGMENT}

The researcher would like to express her greatest gratitude to Ida Sang Hyang Widhi Wasa, for His blessing. Therefore, the researcher could complete this article on time. The researcher also acknowledge with thanks for the people who have given support and motivations to completing this article. My special gratitude my first supervisor I Komang Sulatra, S.S., M.Hum, and my second supervisor I GB Wahyu Nugraha Putra, S.S.,M.Hum for the suggestions and encouragements. The researcher realized that this research far from perfect, therefore, comment and constructive suggestions. Hopefully, this research can be useful for the readers and the next researchers who are interested in field of sociolinguistics especially code switching. 


\section{REFERENCES}

Atmoko Dwi, Bambang. 2012. Instagram Handbook Tips Fotografi Ponsel. Jakarta: Media Kita.

Ayustini, Ni Kadek Mega. 2020. "An Analysis of Code Switching Found in Youtube Channels of Sacha Stevenson". Denpasar: English Study Program, Faculty of Foreign Languages, Mahasaraswati University.

Chaer, Abdul., Agustina, Leonie. 2014. Sosiolinguistik Perkenalan Awal, Edisi Revisi. Jakarta: Rineka Cipta.

Dianti, Desak Eka Virgo. 2018. "Code Switching and The Construction of Young Professional Identity in NET TV's Breakout". Mataram: Faculty of Teacher Training and Education, University of Mataram. Retrieved from http:/ / eprints.unram.ac.id/6939/1/journal\%20pdf.pdf

Hoffmann, Charlotte. 1991. An Introduction to Bilingualism. London and New York: Routledge Taylor \& Francis Group.

Instagram. 2021. Cinta Laura. Retrieved from https://www.instagram.com/claurakiehl/

Nesabamedia. 2020. Pengertian Instagram Beserta Sejarah dan Fungsi Instagram yang Wajib Diketahui Pengguna Internet. From https:/ / www.nesabamedia.com/pengertian-instagram/

Putra, I Gusti Ngurah Bayu Pramana. 2020. “An Analysis of Code Switching Used by Boy William on His Instagram Caption". Denpasar: English Study Program, Faculty of Foreign Languages, Mahasaraswati University.

Romaine, Suzanne. 1989. Bilingualism Second Edition. Oxford: Basil Blackwell Publisher.

Wikipedia. 2021. Cinta Laura Profile. From https://en.wikipedia.org/wiki/Cinta_Laura

Yunandra, Laurentius Pradipta. 2016. "Code Switching in Indonesian Artists' Twitter Tweets". Yogyakarta: Faculty of Teachers Training and Education, Department of Language and Arts Education, English Language Education Study Program, Sanata Dharma University. from https:// repository.usd.ac.id/7928/2/121214097_full.pdf

Zona Referensi. 2019. Pengertian Bahasa. From https://www.zonareferensi.com/pengertian-bahasa/ 